\title{
A DIVULGAÇÃO PELA IMPRENSA DA NOTÍCIA DO DESCOBRIMENTO DO BRASIL POR ÁLVARES CABRAL.
}

Não pertence aos cronitas quinhentistas de Portugal a prioridade da divulgação da notícia do descobrimento da Terra de Santa Cruz por Alvares Cabral, quando da sua viagem para Calicute. Tais cronistas só a partir do comêço do terceiro quartel do século XVI é que começaram a narrar o que ocorreu com a frota de Álvares Cabral quando, para evitar as calmarias do gôlfo de Guiné e os alisados de sudeste, como aconselhava Vasco da. Gama, engolfou-se no Atlântico Sul descobrindo o Brasil.

Logo após o regresso a Lisboa a 23 de junho de 1501 do primeiro navio da frota de Cabral de nome Anunciada, armada por D. Alvaro de Bragança, Bartolomeu Marchioni e mais dois mercadores italianos residentes em Lisboa, diversas personagens de destaque residentes nessa metrópole escreveram para Florença e Veneza, dando notícia do achamento da Terra dos Papagaios. Mas tais mensagens, exclusão feita daquela de Giovanni Matteo Cretico ao doge Agostinho Barbarigo, datada de Lisboa a 27 de junho de 1501, só a partir do comêço do século XIX é que começaram a ser divulgadas pela imprensa.

As primeiras notícias sôbre a viagem de Alvares Cabral à fndia e sôbre o descobrimento do Brasil, foram publicadas em 1505 e 1507 respectivamente em Roma, Milão e Vicência. Isso se explica porque os italianos, notadamente os venezianos, que detinham o monopólio do comércio das especiarias e drogas do Oriente, principalmente no Mediterrâneo oriental e no Mar Negro, onde possuiam vários entrepostos, estavam anciosos em saber o que ocorria com as armadas que Portugal enviava à India visando arrebatar-lhes tal monopólio.

Nos meses de outubro e dezembro de 1505, foi publicada em Roma e Milão, a Copia de una littera del Re de Portogallo mandata al Re de Castella del viaggio e successo de India, opúsculo de 8 fôlhas não numeradas em formato $4 .^{\circ}$. 
Este folheto narra as viagens das quatro primeiras expedições portuguêsas à fndia, a começar pela de Alvares Cabral, fazendo claras alusões ao achamento do Brasil. O tópico dessa carta que faz referência ao descobrimento do Brasil pela segunda armada da Índia é do seguinte teor, segundo a nossa tradução para o vernáculo:

"Neste ano de 1500 no dia 8 de março partiram do pôrto de Lisboa para ir negociar especiarias e drogas na parte da India... Da dita armada foi capitão-mor Pedro Álvares Cabral. Navegando passado o Cabo Verde descobriram novamente uma terra... a qual puzeram o nome de terra de Santa Cruz: isso porque na praia fizeram levantar uma altíssima cruz: outros a chamam Terra Nova ou mais certo Mundo Novo".

Quem primeiro deu notícia da existência dêsse opúsculo, foi Henry Harrisse (1) e ùltimamente Carlos Sanz Lopez (2). São conhecidos quatro exemplares da edição de Roma que se conservam no Museu Britânico, na Biblioteca Marciana de Veneza, na Biblioteca Corsini de Roma, e na The James Ford Bell Collection da Universidade de Minnesota. Da edição de Milão é conhecido um único exemplar que se encontra da referida coleção de James Ford Bell.

Na nossa opinião, essa carta, à semelhança de outros documentos do século XVI, foi forjada. As razões que nos levam a assim raciocinar são as seguintes: tendo $D$. Manuel em 12 de julho de 1499 escrito aos Reis Católicos anunciando o descobrimento do caminho marítimo para a f́ndia por Vasco da Gama, e èm 28 de agôsto de 1501, noticiando o descobrimento do Brasil por Alvares Cabral, não havia necessidade dêsse monarca chover no molhado, escrevendo a carta em tela. Além disso, mais de uma vez, antes de 1505, D. Manuel se avistou com Fernando e Isabel, tendo tido oportunidade de informá-los a respeito do que ocorria com as armadas da fndia em se tratando principalmente do comércio das especiarias.

A carta em aprêço, como já dissemos, é um documento forjado, ficando evidenciado que, para a sua feitura, foram aproveitados tópicos da referida carta que $D$. Manuel enviou aos seus sogros em 28 de agôsto de 1501, da Relação do Pilôto Anô-

\footnotetext{
(1). - Bibliotheca Americana Vetustissima (Addițonș), Paris 187a, páginßs 24 e 25.

(2). - Bibliotheca Americana Vetustissima (Ultimas Adiciones), Madrí, 1960, 1 volume, páginas 381 a 418 , reprodução facsimilar.
} 
mimo e do relato do Padre José. Por outro lado a carta conitém erros que não podiam ter sido praticados por D. Manuel. Um dêles, por exemplo, diz que o comandante da armada que partiu do Tejo em 1502 para a India, foi Pedro Alvares, quan'do em realidade foi Vasco da Gama. Convém frisar que em nenhum arquivo da Europa, inclusive nos de Portugal e Espanha, se encontra qualquer referência a essa carta.

Para satisfazer a curiosidade do povo, os "repórteres" daquela época, de comum acôrdo com os impressores, tôda a vez que podiam obter uma cópia das cartas ou dos relatórios que os navegantes, ao voltarem das suas viagens, enviavam às pessoas amigas ou aos monarcas a quem serviam, mas por escopo comercial do que por outro qualquer motivo, compilavam tais informações e enxertavam narrações plenas de tôda a sorte de fantasias e as imprimiam com a possível urgência em folhetos que, como os jornais de agora, eram vendidos nas feiras, às portas das igrejas e em outros lugares onde o povo se aglomerava.

Em 1507 foi publicada pela primeira vez na cidade de Vicência, uma coletânea de descrições de viagens e descobrimentos marítimos organizada pelo professor de literatura de nome Fracanzano da Montalbodo, sob o título: Paesi Novamente Retrovati et Novo Mondo da Alberico Vesputio Florentino Intitulato. Essa coletânea divide-se em seis partes, sendo que cada parte é denominada Libro. Parte do Libro Secundo e todo - Libro Tertio são os que mais nos interessam, por narrarem a viagem de Alvares Cabral a Calicute e o descobrimento do Brasil por êste capitão-mor.

A descrição dessa viagem é conhecida entre nós com o nome de Relação do Pilôto Anônimo, devido ao fato de ter sido traduzida em 1812 pela Academia das Ciências de Lisboa da obra de Giovanni Baptista Ramúsio, publicada em Veneza em 1550, sob o título de Navegationi e Viaggi, sendo que Ramúsio 'erradamente atribui a sua autoria a um pilôto anônimo português. As modernas investigações históricas (3) chegaram ao seguinte resultado sôbre o autor da descrição da viagem de $\mathrm{Ca}$ bral ao Brasil e a Calicute, publicada pela primeira vez por Montalbodo: Pedro Martyr de Angleria, homem de notável saber, o primeiro historiador do descobrimento da América, escreveu em latim uma narrativa completa das três primeiras viagens de Colombo e daquelas de Alonso Niño e Vicente Yañez

(3). - Raccolta Colombina, parte III, Guglielmo Berchet, Carteggi Diplomatiei. 
Pinson, tendo mandado tirar cópias dêsse seu trabalho a fim. de oferecê-las a amigos da Itália. Uma dessas cópias, que era a primeira década de sua notável obra De Rebus Oceanícis et. Novo Orbe, foi ter às mãos de Ângelo Trevisan, secretário da. embaixada de Veneza na Espanha.

Ora, como Trevisan recebia cartas do almirante Domênico: Malipiero, um dos historiadores da grandeza de Veneza, nas. quais manifestava enorme interêsse pelos recentes descobrimentos marítimos realizados pelos espanhóis e portuguêses, es-. creveu Trevisan, de Granada, a 21 de agôsto de 1501 ao referido. almirante, dizendo que ia traduzir para o veneziano vulgar a. narrativa de Pedro Martyr e fazer-lhe pouco a pouco a remessa da mesma, visto não poder remetê-la de uma só vez, porser muito extensa. Após ter recebido a aludida tradução e ti-rado dela os apontamentos de que necessitava, Malipiero a ofereceu ao Senado de Veneza, sendo que o manuscrito foi ter às. mãos de Albertino Vercellese da Lisona, que o fêz imprimir. em 1504 sob o título: Libretto De Tutta la Navigatione De Re: Spagna De Le Isole et Terreni Novamente Trovati .

Mas Malipiero não se contentava com os pormenores das: viagens de Colombo e pediu a Trevisan que lhe enviasse também informações sôbre a viagem de Cabral a Calicute. Dan-. do desempênho a essa incumbência de Malipiero, pediu Trevisan a Giovanni Matteo Crético, núncio de Veneza em Lisboa, que lhe enviasse uma minuciosa narrativa do que ocorrera com. a segunda armada portuguêsa da fndia, sob o comando de Alvares Cabral.

$\mathrm{Na}$ referida carta de 21 de agôsto de 1501, Trevisan além: de informar Malipiero sôbre o que tinha obtido com relação a viagem de Colombo, declara:

"Estar esperando de dia para dia o nosso doutor (Crético), de Lisboa, que lá deixou o nosso magnifico embaixador (Domênico Pisani), o qual a meu pedido fêz. um pequeno trabalho sôbre a viagem de Calicute, do. qual tirarei uma cópia para Vossa Magnificência".

Mas ao que parece, Malipiero insta com Trevisan por informações da viagem de Calicute, e o secretário da embaixada de Veneza na Espanha, provàvelmente em setembro dêsse mesmo ano, escreve novamente a Malipiero dizendo que:

“Com relação ao desêjo que Vossa Magnificência tem de inteirar-se a respeito da viagem de Calicute, eu já vos. escrevi que, de dia para dia estou esperando Messer Cré-- 
tico que me escreve dizendo ter feito um pequeno trabalho. Assim que êle chegue, farei com que Vossa Magnificência receba uma parte".

Está dêsse modo confirmado que Crético escreveu um relato sôbre a viagem de Alvares Cabral a Calicute. Finalmente em 3 de' dezembro, de Exigia, escreve Trevisan uma nova carta a Malipiero, onde há esta passagem:

"Messer Crético, profundamente leal servidor de Vossa Magnificência, vos agradece por tê-lo saudado tão amàvelmente em vossas cartas, e muito se recomenda, congratulando-se do fundo do seu coração pelas vossas felicidades. Ele veio de Portugal em fins de setembro muito bem informado no que diz respeito à viagem de Calicute e está escrevendo uma narração que será muito bonita e agradável a quem se deleita com tal coisa".

Essa relação da viagem de Alvares Cabral, tão desejada mas tão retardada, só chegou a Veneza depois de ter sido publicado em 1504 o Libretto, para sair em 1507 na coletânea de Montalbddo.

A correspondência a que fizemos alusão, aquela de Trevisan ao almirante Domênico Malipiero, foi por êste oferecida ao Senado de Veneza, dali passou às mãos de Soranzo, patrício vêneto, e depois dêle às de duas ou três pessoas, até que foi cair em poder do reverendo Walter Sneyd, de Londres. Por morte do reverendo Walter, tornou-se propriedade de seu filho, sendo hoje em dia conhecida por Códice Sneyd. Atualmente está na Biblioteca do Congresso em Washington.

O Paesi de Montalbodo publicou pela primeira vez a narração das viagens de $\mathrm{Ca}^{\prime}$ da Mosto ao Cabo Verde e ao Senegal, quando a serviço do infante $\mathrm{D}$. Henrique; o relato da viagem de Vasco da Gama à India; idem daquele da viagem de Álvares Cabral ao Brasil e Calicute; o despacho de Giovanni Mateo Crético, núncio de Veneza em Lisboa, ao doge Agostitinho Barbarigo, onde há referência ao descobrimento do Brasil por Álvares Cabral; a narrativa da viagem de Vespucci ao nosso país em 1501-1502, quando a serviço do rei D. Manuel, mais conhecida por Mundus Novus. Além disso, êsse livro publicou pela segunda vez a descrição das três primeiras viagens de Colombo, da de Alonso Niño e da de Vicente Yañez Pinzon. Termina o Paesi com o relato do Padre José, onde há referência à viagem de Álvares Cabral, aos cristãos de Cranganor e aos costumes dos habitantes da India. 
Eis agora a tradução da parte dêsse livro relativa ao descobrimento do Brasil por Alvares Cabral, feita por nós diretamente da edição princeps existente na Biblioteca Nacional do Rio de Janeiro:

\author{
Livro Segundo. \\ Capítulo LXIII. \\ Onde em pessoa o rei D. Manuel entregou o estandarte \\ ao capitão .
}

No ano de 1500 mandou o sereníssimo rei de Portugal por nome chamado Dom Manuel, uma armada sua composta de naus e navios a qual tinha por capitão geral Pedro Aliares Cabrile (Pedro Alvares Cabral), fidalgo. Estas naus e navios partiram bem aprestados e providos de tudo o de que precisassem por ano e meio. Dessas 12 naus ordenou que 10 descarregassem em Calicute e que as outras 2 fôssem à Arábia, ficando estabelecido que fôssem a um lugar chamado Zaffalle (Sofala) porque queriam contratar mercadorias no dito lugar; e aquêle lugar de Sofala acha-se estar no caminho de Calicute. $E$ assim as outras 10 naus levassem mercadorias que para a dita viagem lhes fôssem necessárias.

$\mathrm{E}$ aos 8 do mês de março do dito milésimo ficaram prontas e naquele dia de domingo sairam fora desta cidade duas milhas distantes para um lugar chamado Rastello, onde há uma igreja chamada Santa Maria de Ballar (Belém), no qual lugar o Sereníssimo Rei foi êle mesmo em pessoa entregar ao capitão o estandarte real para a dita armada.

Item. Na segunda-feira que foi 9 de março partiu a dita armada para a sua viagem, com bom tempo.

Item. Aos 14 do dito mês passou a dita armada pela ilha da Canária.

Item. Aos 23 desgarrou uma nau da dita armada de modo que desta nunca se soube notícia até o presente, nem se pode saber.

\title{
Capítulo LXIII.
}

Como correram as naus com a tempestade.

Aos 24 de abril que foi a quarta-feira da oitava da Páscoa, teve a dita armada vista de uma terra, com o que houve grande prazer. E chegaram a terra para ver que terra era, a qual terra acharam muito abundante de árvores e gentes, que por ali andavam pela praia do mar. E lançaram âncora na foz de um pequeno rio. E depois de lançadas ditas âncoras o capitão mandou arriar um batel ao mar no qual mandou ver que gentes eram aquelas. E acharam que eram gentes de côr parda, entre o branco e o prêto, bem dispostas, com cabelos compridos. Andam nus, como nasceram, sem ver- 
gonha alguma. E cada um dêles trazia seu arco com flechas, como homens que estavam em defesa do dito rio. $\mathrm{Na}$ dita armada não havia ninguém que entendesse sua língua e, visto isso, os do batel voltaram ao capitão. E nesse instante se fêz noite, na qual houve grande tempestade.

Item. No dia seguinte pela manhã levantamos âncora com grande tempestade e andamos correndo a costa para o norte, para vermos se encontrávamos algum pôrto onde ficasse dita armada. O vento era sueste. Finalmente achamos um pôrto onde lançamos âncora no qual encontramos daqueles nativos que andavam nos seus barquinhos pescando. E um dos nossos batéis foi onde êstes tais homens estavam e aprisionaram dois dêles e trouxeram ao capitão para saber que gente era. E, como foi dito, não se entendiam por fala e menos por acenos. E naquela noite o capitão os reteve consigo. No dia seguinte os mandou vestir com uma camisa, uma roupa e um barrete vermelho. $\mathbf{E}$ por vestir, ficaram muito contentes e maravilhados das coisas que lhes foram mostradas. Depois daquilo mandou deitá-los à terra.

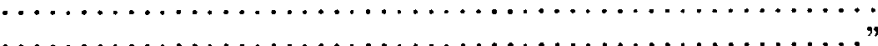

Como já dissemos, logo após o retôrno a Lisboa, a 23 de junho de 1501, do primeiro navio da frota de Alvares Cabral de nome Anunciada, o núncio de Veneza em Lisboa, de nome Giovanni Matteo Crético, escreveu ao doge Agostinho Barbarigo, em 27 de junho de 1501, uma carta na qual resumidamente se refere ao ocorrido com a segunda armada da Índia e relata o descobrimento da Terra de Santa Cruz.

Essa carta foi publicada no Paesi em 1507 e o tópico que diz respeito ao achamento do Brasil por Alvares Cabral é do seguinte teor:

"Acima do cabo da Boa Esperança, do lado de sudoeste, descobriram uma terra nova, chamam-na dos Papagaios, por serem êles do comprimento de um braço e mais, de várias côres, dos quais vimos dois".

Uma cópia dessa carta foi seguramente remetida ao referido doge por intermédio de Pietro Pasqualigo, embaixador de Veneza em Lisboa, e uma segunda cópia por meio de Domênico Pisani, embaixador também de Veneza na Espanha. A cópia remetida por Pisani foi trasladada por Marino Sanuto nos seus Diarili, só publicados em 1881 . 
De 1507 até 155!, quando os cronistas portuguêses começaram a narrar a viagem de Álvares Cabral, nenhum nôvo relato foi publicado com relação ao descobrimento do Brasil. Apenas se constata que a referida coletânea de Montalbodo teve grande popularidade, pois foi reimpressa em Milão em 1508, 1512 e 1519; em Veneza em 1517 e 1521; traduzida para o latim em 1508, por Archangelo Madrignano com o título Itinerarium Portugallensium; para o alemão por Jobst Ruchamer, em 1508; para o francês em 1515, 1516, 1521 e 1528. Foi reproduzida em latim em 1532, na coletânea organizada por Johannes Huttichius e prefaciada por Simon Gryneaus, intitudada Novus Orbis Regio.

Os cronistas quinhentistas portuguêses que escreveram sôbre o descobrimento do Brasil por Alvares Cabral, foram os seguintes pela ordem cronológica:

Fernão Lopes de Castanheda, que teve a sua crônica publicada pela primeira vez em 1551, assim descreve o que ocorreu com a frota de Cabral ao partir das ilhas de Cabo Verde, rumo ao Cabo da Boa Esperança:

"Desaparecida a caravela de Luís Pires esperou Pedro Álvares Cabral por ela dois dias, e aos vinte quatro de abril que foi derradeira oitava da Páscoa foi vista terra, e que era outra costa oposta à da África, e demorava a oeste, e reconhecida a terra pelo mestre da capitânea que lá foi, mandou Pedro Alvares surgir para fazer aguada e a descobrir, e por o pôrto em que surgiu ser bom, lhe pôs nome pôrto seguro".

"Desta terra mandou Pedro Álvares a Gaspar de Lemos na sua caravela com cartas a el-Rei D. Manuel, em que dizia o que lhe até ali tinha acontecido, e mandoulhe um homem daquela terra, e ao outro dia que foram 3 de maio partiu-se Pedro Álvares Cabral com tôda a frota, levando a rota do Cabo da Boa Esperança", etc. (4)

João de Barros, considerado o Tito-Lívio dos portuguêses, autor da famosa crônica conhecida por Décadas da Ásia, cuja primeira década foi publicada em 1552, descreve o descobrimento do Brasil do seguinte modo:

(4). - História dos Descobrimentos e Conquista da fndia pelos Portuguêses, Lisboa, 1883, livro I, capítulo XXXI, páginas 97 e 98 . 
* Junta a frota depois que passou o temporal, por fugir da terra de Guiné onde as calmarias lhe podiam impedir seu caminho: empregou-se muito no mar por lhe ficar seguro poder dobrar o cabo da Boa Esperança. E havendo já um mês que ia naquela grande volta, quando veio a segunda oitava da Páscoa que eram 24 de abril, foi dar em outra costa de terra firme: a qual segundo a estimação dos pilotos lhe pareceu que podia distar para oeste da costa de Guiné quatro centas cincoenta léguas, e em altura do polo antártico da parte do sul dez graus" (5).

Damião de Góes foi nomeado por D. João III, cronista-mor do reino e exerceu o alto cargo de guarda-mor da Tôrre do Tombo. A primeira edição da sua crônica sôbre o Rei D. Manuel foi publicada em 1566 e nela é encontrada o seguinte tópico sôbre o descobrimento do Brasil por 'Alvares Cabral:

"Ao outro dia pela manhã que foram 9 de março de 1500 , partiu a frota do pôrto de Belém com bom vento de foz em fora, e aos 14 houve vista das ilhas das Canárias, e aos $22 \mathrm{com}$ vento próspero passou pela ilha de Santiago, avante da qual se apartou da frota com tormenta a nau de que era capitão Luís Pires, que arribou a Lisboa desbaratada, por cujo respeito andou Pedro Álvares Cabral ao pairo com tôda a armada dois dias, mas vendo que não aparecia, seguiu sua viagem, e navegando a oeste, aos 24 dias do mês de abril viram terra, do que foram mui alegres, porque pelo rumo em que jazia não ser nenhuma das que até então eram descobertas..." (6).

Jerônimo Osório, bispo de Silves, encacregado pelo cardeal D. Henrique, regente da corôa de Portugal, durante a menoridade de D. Sebastião, de escrever a vida do rei $\mathrm{D}$. Manuel, compôs: De Rebus Emmanuelis, regis lusitaniae invictissimi virtute et auspicio, etc., publicada em Lisboa em 1571. A tradução para o português, feita por Francisco Manuel do Nascimento (Felinto Elísio) foi publicada em 1808 e reeditada em 1944. Narra Osório o descobrimento do Brasil por Cabral, do seguinte modo:

"Mas Pedro Álvares Cabral, que ia em derrota da India, seguindo a mesma esteira do Gama, veio à ilha de Santiago; donde querendo passar avante, tal tormen-

(5). - Décadas da Asia, Lisboa, 1628, década 1, livro V, capítulo II, fôlhas 87 e 88 .

(6). - Chronica do Felicissimo Rei Dom Manuel, Lisboa, 1566, volume I, fôlha 51 e verso. 


\begin{abstract}
ta se levantou que a armada se lhe desgarrou, e uma das naus desarvorada recuou para Lisboa. Aplacada a tempestade, cuidou Cabral em recolher a si a armada, em que achou aquela nau de menos, pelo que mandou arrear as vergas e esperar por ela dois dias. Vendo porém que não aparecia, pôs a proa no Ocidente. A vinte e quatro de abril descobriram os gajeiros terras, de que todos conceberam incrível contentamento, não havendo nenhum dos nossos que tivesse a menor suspeita de que lhes demorasse terra habitada de homens por semelhantes paragens", etc. (7).
\end{abstract}

Gaspar Coreria que viveu na India poucos anos depois de ter sido ela encontrada por Vasco da Gama, escreveu a sua crônica entre 1529 a 1561, mas só foi ela publicada em 1858 pela Academia das Ciências de Lisboa. Na nossa opinião, essa demora em ser impressa a obra de Gaspar Correia, deve-se atribuir a êste cronista verberar as atrocidades praticadas pelos portuguêses na fndia. Com as seguintes palavras narra êle o descobrimento do Brasil por Alvares Cabral:

"A capitânea que ia diante, amanhecendo um domingo houve vista de terra a barlavento, ao que fêz sinal com tiro de berço, e foi correndo para ela, e a descobrindo que era grande costa, terra nova, que nunca fôra vista, correndo ao longo dela, viram grandes arvoredos pelas fraldas do mar e por dentro grandes montes e serrarias, e muitos rios largos e grandes enseadas".

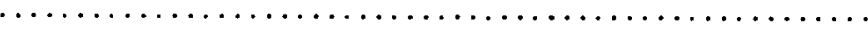

"Onde o capitão-mor por conselho de todos, d'aqui tornou a mandar ao reino o navio de André Gonçalves, com a nova a el-Rei desta nova terra que descobrira", etc. (8).

A primeira História do Brasil foi escrita em Portugal por Pero de Magalhães Gandavo, com o título: História da Província de Santa Cruz. O descobrimento do nosso país pela segunda armada portuguêsa da Índia, é assim narrado:

" $E$ havendo já um mês que iam naquela volta, navegando com vento próspero, foram dar na costa desta província; ao longo da qual cortaram todo o dia, parecendo a todos que era alguma grande ilha que ali es-

\footnotetext{
(7). - Da Vida e Feitos de El-Rei D. Manuel, Pôrto, 1944, volume 1, páginas 86 a 88 .

(8). - Lendas da india, Lisboa, 1858, volume 1, páginas 151 a 152.
} 
taria, sem haver pilotos nem outra pessoa alguma que tivesse notícias dela, nem que presumisse que podia estar por aquela parte ocidental" (9).

Depois das narrativas dos cronistas quinhentistas de Portugal, a notícia da viagem de Alvares Cabral ao Brasil e a fndia foi amplamente divulgada pela imprensa devido principalmente a terem sido traduzidas para o italiano, francês e inglês, as obras dêsses cronistas.

Porém o interessante em tudo isso é que os mais importantes documentos que foram redigidos no comêço do século XVI sôbre o achamento do Brasil por Álvares Cabral, só a partir do comêço do século XIX é que principiaram a ser divulgados pela imprensa, como vamos ver.

As pesquisas feitas até hoje evidenciam que a carta de $\mathrm{Pe}$ ro Vaz de Caminha ao rei D. Manuel, expedida de Pôrto Seguro a $1 .^{\circ}$ de maio de 1500 , dando notícia do achamento de Vera Cruz e indicando a data certa dêsse acontecimento, não foi divulgada de nenhuma maneira. De fato, todos os cronistas portuguêses, a começar pelos do século XVI, que escreveram sôbre o descobrimento do nosso país por Alvares Cabral, dizem que o acontecimento ocorreu a 24 de abril de 1500 , quando em realidade foi a 22 dêsse mês.

O historiador espanhol Juan Bautista Muñoz teve oportunidade de realizar pesquisas no arquivo da Tôrre do Tombo de Lisboa, encontrando a carta que Caminha escreveu a D. Manuel (gaveta 8, manuscrito 2, n.o 8), da qual fêz um extrato. Em 1793 publicou Muñoz o primeiro volume da sua Historia del Nuevo Mundo, mas nêle não foi estampado o extrato aludido nem em nenhuma outra publicação de sua autoria.

Quem primeiro divulgou pela imprensa a carta de Vaz de Caminha foi o padre Manuel Aires de Casal em 1817 (10), porém mutilada nas passagens que julgou ofensivas ao pudor.

Logo após o retôrno da frota de Alvares Cabral da sua viagem à fndia, o rei $\mathrm{D}$. Manuel escreveu aos Reis Católicos uma carta dando notícia do ocorrido com essa armada, inclusive do descobrimento do Brasil.

\footnotetext{
(9). - História da Província de Santa Cruz, Lisboa, 1576, capítulo 1, fôlha 6.

(10). - Corografia Brasílica, Rio de Janeiro, 1817, Imprena Régia, volume 1, páginas 12 a 34 .
} 
O grande historiador espanhol Martin Fernandez de Navarrete (11) publicou uma versão espanhola dessa carta, dizendo textualmente que:

"Existia en Zaragoza, en el Archivo de la Antiga Diputación de Aragon, destruido en la guerra de la Independencia. Copia sacada por don Joaquin Traggia".

De acôrdo com esta versão espanhola, a carta em tela foi expedida de Santarém a 29 de julho de 1501 .

Dessa carta existe uma cópia em português no Arquivo de Veneza, publicada pelo professor italiano Belgrano (12). A cópia revela que a carta foi remetida de Lisboa a 29 de agôsto de 1501 , sendo que o tópico referente ao descobrimento do Brasil está assim redigido:

"O meu dito capitão (Pedro Álvares Cabral) com treze naus partiu de Lisboa a nove dias de março do ano passado e nas oitavas de Páscoa seguinte chegou a uma terra que novamente descobriu a que pôs nome Santa Cruz, em que achou as gentes nuas como na primeira inocência, mansas e pacíficas, a qual pareceu que Nosso Senhor milagrosamente quis que se achasse porque é mui conveniente e necessária à navegação da índia, porque ali corrigiu suas naus e tomou água, e pelo caminho grande que tinha para andar não se deteve para se informar das coisas da dita terra, sòmente dali me enviou um navio e a notificar-me como a achara, e seguiu seu caminho pela via do cabo da Boa Esperança" (13) .

Como se vê do tópico acima transcrito da carta que D. Manuel enviou a Fernando e Isabel em 29 de agôsto de 1501, o monarca português diz que o achamento do Brasil por Alvares Cabral era conveniente e necessária à navegação da Índia. Dêsse modo pensavam os escritores: tôdas as armadas enviadas à fndia, fizessem escala em Vera Cruz. Mas o contrário ocorreu. João da Nova que partiu de Lisboa para a India na primeira quinzena do mês de março de 1501, não escalou na região de Pernambuco. Não escalaram no território brasileiro as armadas de Vasco e Estêvão da Gama, de

(11). - Coleccion de los viajes y descubrimientos que hicieron por mar los espafioles desđe fines siglo XV. Madrí, 1825-1837, volume III, páginas 94 a 101 .

(12). - Bolletino della Societá Geografica Italiana, 1890, terceira série, volume III, páginas 271 e seguintes.

(13). - T. O. Marcondes de Souza, o Descobrimento do Brasil, segunda ediçāo, São Paulo, 1956, páginas 289 a 295. 
Afonso e Francisco de Albuquerque, de Lopo Soares e de Francisco de Almeida, que desferraram de Lisboa para a fndia respectivamente em 1502,1503, 1504 e 1505 . Há quem admita ter "Tristão da Cunha, em 1506, na sua acidentada travessia, avistado terras do Brasil. Daí por diante não se tem notícia segura de ter qualquer frota portuguêsa em viagem para a índia, escalado no nosso país.

Mestre João, Mestre Menelau, Mestre Joan Faras, galego, grego ou alemão, físico e cirurgião de D. Manuel, escreveu a êste monarca de Pôrto Seguro em 1..$^{\circ}$ de maio de 1500 uma carta na qual muito pouca coisa diz sôbre o descobrimento de Vera Cruz por Alvares Cabral, ocupando-se mais da astronomia náutica e de cálculos de latitude e longitude.

Essa carta dormiu durante mais de 300 anos no Arquivo da Tôrre do Tombo, até quando foi encontrada pelo sábio historiador brasileiro Francisco Adolfo de Varnhagen que a publicou em 1843 no tomo V, página 342 e seguintes da Revista do Instituto Histórico e Geográfico Brasileiro.

A carta foi escrita em espanhol aportuguesado, sendo que certos historiadores procuram atribuir a Mestre João a prioridade de ter observado e descrito a constelação do Cruzeiro do -Sul, quando em realidade tal prioridade pertence ao navegador veneziano Alvise de Ca' da Mosto (14).

Valentim Fernandes, alemão natural da Morávia, gozou de grande prestígio nas côrtes portuguêsas. Foi impressor, tradutor, autor, epistolário, tabelião público em Lisboa e até escudeiro da rainha D. Leonor, espôsa de D. João II e irmã de D. Manuel.

Em um ato notarial de sua autoria redigido em latim em 20 de maio de 1503 , em Lisboa, para acompanhar a imagem de um tupí e a pele de um jacaré, enviados a Burgos por um mercador flamengo, cujo original se extraviou, existindo porém um traslado feito e autenticado por um tabelião de Colônia de nome Silvério Wigenhorst, a pedido de certo Conrado von der Rosen, existe uma passagem sôbre o descobrimento do Brasil por Alvares Cabral do seguinte teor:

"Uma armada de treze grandes navios do poderosíssimo Manuel I, rei de Portugal e dos Algarves de aquém e de além mar em África e senhor de Guiné e da conquista, navegação e comércio da Etiópia, Arábia,

(14). - Fracanzano da Montalbbodo, Paesi novamente retrovati e Novo Mondo da Alberico Vesputio florentnio intitulato, Milano, 1508, livro 1, capítulo XXXIX, página 50 . 
Pérsia e India, cujo comandante era o estrênuo cavaleiro Pedro Álvares Cabral, saída do pôrto e riquíssimo empório lisbonense e dirigida para a India, aquém do Ganges, pela Divina Providência descobriu para nós,. no incógnito mar, sob a linha equinocial, no ano do parto da Virgem de 1500 , no último dia de abril, outro. orbe desconhecido de todos os autores, cujos incolas, não tendo nem fé, nem religião, nem idolatria, nem qualquer conhecimento do seu Criador," etc. (15).

O documento em aprêço faz parte do célebre Códice Conrado Peutinger que se encontra na Biblioteca de Stuttgart [Notariatsakt in der Überlieferund unseres cod. hist. fol. 248 , fol. 54-55 (Codex Peutingerianus)]. Quem primeiro o divulgou foi. Frederico Kunstmann em 1860 (16).

Em 1898 o historiador alemão Kurt Trubenbach divulgou: parte dêsse documento ao estudar a segunda viagem de Vespucci ao Novo Mundo (17), o mesmo tendo feito em 1924 o professor italiano Alberto Magnaghi (18). Porém só em 1939 é que. tal documento foi divulgado entre nós na íntegra, graças ao historiador português A. Fontoura da Costa (19), que o traduziu. para o vernáculo e publicou-o, porém com pequenos erros.

Em 1958 obtivemos um micro-filme do referido ato notarial de Valentim Fernandes que nos foi enviado gentilmente pelo Dr. Helmut Kaempf, diretor da Biblioteca de Stuttgart. Tal documento foi traduzido do latim para o português pelo. professor Torquato de Souza Soares e publicado na Revista de História (20).

Fazendo pesquisas na Biblioteca Riccardiana de Florença: para escrever o melhor trabalho até hoje conhecido sôbre a viagem de Alvares Cabral (21), o notável historiador norteamericano William Brooks Greenlee encontrou por cópia, no Códice Riccardiano 1910, duas cartas que o banqueiro e mercador florentino de nome Bartolomeu Marchioni enviou a Florença para a pessoa desconhecida, relatando a viagem de Cabral e

\footnotetext{
(15). - T. O. Marcondes de Souza, Algumas Achegas à História dos Descobrimentos Marítimos, São Paulo, 1958, páginas 263 a 272.

(16). - Valentim Ferdinand's Beschrieibuhg der Westküst Africa vom Senegai bis zur Serra Leoa (in: Abhand der Hist. - Akademie d. Wiss. Band. VIII, 1856; Band III, 1860; Band I, 1861). Munchen.

(17). - Amerigo Vespucci's Reise nach Brasilien, Plausen, 1898.

(18). - Amerigo Vespucci, studio critico, Roma, 1924, volume II, página 189.

(19). - Cartas das nhas de Cabo Verde de valentim Fernandes, 1506-1508, Lisboa, 1939, páginas 91 a 93 .

(20). - Órgāo do Departamento de História da Faculđade de Filosofia, Ciências e Letras da Universidade de São Paulo, volume 34 (abril-junho de 1958), páginas 369 a 378 .
} 
fazendo ligeira referência ao descobrimento do Brasil por êste capitão-mor. Essas cartas, antes das pesquisas de Greenlee, tinham passado despercebidas aos raros estudiosos que compulsaram tal códice, inclusive o notável professor italiano Gustavo Uzielli.

Essas cartas foram publicadas pela primeira vez em 1938 por Greenlee na sua citada obra, sendo de grande valor para o estudo do comércio das especiarias pelos portuguêses, uma vez que se trata de um banqueiro que gozava de excepcionais favores do Govêrno Português, tanto assim que incorporava a sua custa em cada armada que partia de Lisboa à Índia, a principiar pela de Álvares Cabral, uma nau para o transporte de especiarias.

Como já dissemos, duas cartas escreveu Marchioni sôbre o retôrno da frota de Cabral; uma entre 24 e 30 de junho e outra depois de 21 de julho de 1501 . E' nesta última carta onde se encontra um pequeno tópico sôbre o descobrimento do Brasil do seguinte teor:

"Esste rei (D. Manuel) achou recentemente nesta (viagem) um nôvo mundo, mas é perigoso navegar sôbre a extensão dêsses mares" (22).

Assiste tôda a razão a Marchioni quando diz que "é perigoso navegar sôbre a extensão dêsses mares", visto que após ter Cabral passado as ilhas de Cabo Verde em demanda do cabo da Boa Esperança, perdeu mais da terça parte dos navios de sua frota: a nau de Vasco de Ataíde que desgarrou na altura do citado arquipélago e não mais apareceu; as de Bartolomeu Dias, Simão de Pina, Aires Gomes e Luís Pires, que naufragaram no trajeto Pôrto Seguro-Cabo da Boa Esperança. Ao todo cinco navios dos trezes que somava a frota de Cabral.

Como vimos, as cartas que Caminha e Mestre João enviaram de Pôrto Seguro a $1 .^{\circ}$ de maio de 1500 , ao rei D. Manuel, estiveram nas gavetas do Arquivo da Tôrre do Tombo, sem serem divulgadas, durante 317 e 343 anos respectivamente. A missiva de D. Manuel aos Reis Católicos narrando a viagem de Cabral, só foi publicada 336 anos depois de escrita. $\mathrm{O}$ ato notarial de Valentim Fernandes de 20 de maio de 1503, foi divulgado pela imprensa, 357 anos depois de lavrado. E, para finalizar, as cartas que Bartolomeu Marchioni en-

(21). - The Voyage of Pedro Alvares Cabral to Brasil and India. Printed for the Hakuluyt Society, London, MCMXXXVIrI.

(22). - William Brooks Greenlee, obra citada, pagina 149. 
viou a Florença, descrevendo a viagem de Alvares Cabral, foram publicadas 438 anos depois de expedidas.

De Pôrto Seguro, segundo Caminha, todos os capitães escreveram a D. Manuel dando notícia do achamento do nosso país. No entanto, de tôda a correspondência expedida, só foram encontradas até hoje apenas duas cartas que não são de capitães nem de pilotos.

Inúmeros documentos de valor foram extraviados por desleixo daqueles que tinham por obrigação zelar pela conservação e divulgação de preciosos documentos que constituiram inegàvelmente rico patrimônio da nação.

O notável historiador brasileiro, Francisco Adolfo de Varnhagen, adquiriu de um antiquário de Madrí as instruções que Vasco da Gama ditou para a viagem de Alvares Cabral. e as publicou em fascimile em 1854, na sua História Geral do Brasil. Em seguida ofertou êsse precioso documento ao Arquivo da Tôrre do Tombo onde, como diz o insuspeito historiador português Damião Peres, esteve abandonado e esquecido por longos anos, desde ignorada data, pois a não tem a missiva oferta, até 1934, ano em que Antônio Baião, diretor daquele estabelecimento, providencialmente achou no canto duma gaveta, ainda dentro do sobrescrito em que viera (23) .

No entanto alguns escritores, sem o menor escrúpulo, por desmedida vaidade nacional, procuram explicar essa e outras incúrias recorrendo à "política de sigilo" dos monarcas portuguêses da época dos descobrimento, processo fácil mas não elegante de justificar o desmazêlo dos arquivistas portuguêses.

$\mathrm{E}$, que "política de sigilo" era essa que não pôde evitar que Alberto Cantino enviasse de Lisboa a Hercule D'Este, duque de Ferrara, grande planisfério desenhado por um cartógrafo português; que facilitou aos estrangeiros; notadamente aos venezianos, obterem cópias de sigilosos documentos, como por exemplo, da missiva que D. Manuel enviou a Fernando e Isabel, dando notícia da viagem de Alvares Cabral ao Brasil e a Calicute?!

\section{T. O. MARCONDES DE SOUZA}

Da Sociedade de Estudos Históricos de São Paulo e da Société des Américanistes de Paris.

(23). - História dos Descobrimentos Portuguêses, Pôrto, 1943, páginas. 382-383. 